DOI No: http://dx.doi.org/10.29228/Joh.54047

Authenticity process is conducted by

Makale Türü: Araştırma makalesi

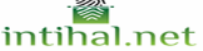

Geliş Tarihi: 02-11-2021

Kabul Tarihi: 02-12-2021

On-line Yayın: 30-12-2021

Article Type: Research article

Submitted: 02-11-2021

Accepted: 02-12-2021

Published Online: 30-12-2021

Atıf Bilgisi / Reference Information

Akınc1, B. (2021). The Public-Private Partnership Model in the New Public Management Paradigm: An Evaluation on Dualist Administrative Structures of City Hospitals. Journal of History School, 55, 3845-3866.

\title{
THE PUBLIC-PRIVATE PARTNERSHIP MODEL IN THE NEW PUBLIC MANAGAMENT PARADIGM: AN EVALUATION ON DUALIST ADMINISTRATIVE STRUCTURES OF CITY HOSPITALS ${ }^{1}$
}

\section{Berat AKINCI ${ }^{2}$}

\begin{abstract}
After the Second World War, the understanding of the welfare state, which prevailed in meeting the demands and expectations of the citizens, led to the excessive growth of the public sector over time. These developments, which have made themselves felt on a global basis since the 1980s and formed the basis of new public management, have enabled some public services to be performed by benefiting from the business technique and financial resources of the private sector. Thus, some public-private partnership models have emerged in order to provide public services effectively and efficiently as a result of a market-based approach. The public-private partnership model, which was applied in the health sector in many European countries, especially in the UK, in the early 1990s, started to be implemented in our country within the scope of the health transformation program that started in 2003. Subsequently, the Law No. 6428 of 2013, which defines the public-private cooperation in clearer lines, "Building, Renovation and Service by Public-Private Partnership Model, and Amending Certain Decree Laws" was

${ }^{1}$ This study is the expanded and revised version of the paper presented at the Congress of Social Sciences conducted by the 1st International CEO (Communication, Economics, Organization) in Grozde, Bosnai Hercegovin between 18 th - 20 th December, 2020.

${ }^{2}$ Assoc. Prof., Adana Alpraslan Türkeş Science and Technology University, Faculty of Political Science, Department of International Relations, bakinci@atu.edu.tr, Orcid:0000-0002-52395417
\end{abstract}




\section{Berat AKINCI}

adopted. In the city hospitals projects planned to be implemented within the scope of this law, it is foreseen that the construction of 18 hospitals will be completed by the private sector and delivered to the Ministry of Health by the end of 2021. However, this system, which is new in health service delivery, has a double-headed organizational and managerial structure that ensures that core health services are provided by the public sector and other support services by the contractor firm. Therefore, in this study, the administrative structures of city hospitals, which contain a new situation in terms of authority and responsibility balances, are analyzed and solutions are offered for possible problems.

Keywords: New Public Management, Public-Private Partnership, City Hospitals.

\section{Yeni Kamu İşletmeciliği Paradigmasında Kamu-Özel Ortaklık Modeli: Şehir Hastanelerinin Düalist Yönetsel Yapıları Üzerine Bir Değerlendirme}

\section{$\ddot{\mathbf{O} z}$}

1980'li yıllardan itibaren küresel bazda kendini hissettiren ve yeni kamu işletmeciliğinin temelini oluşturan gelişmeler, bazı kamu hizmetlerinin özel sektörün işletme tekniğinden ve finans kaynaklarından yararlanılarak yerine getirilmesine olanak sağlamıştır. Böylelikle piyasa temelli anlayışın getirisi olarak kamu hizmetlerinin etkin ve verimli bir şekilde sunulması adına bazı kamu-özel ortaklık modelleri ortaya çıkmıştır. 1990'ların başında başta İngiltere olmak üzere birçok Avrupa ülkesinde sağlık sektöründe uygulanan kamu-özel ortaklık modeli, 2003 yılında başlayan sağlıkta dönüşüm programı kapsamında ülkemizde de uygulanmaya başlanmıştır. Akabinde kamu-özel işbirliğini net çizgilerle belirleyen 2013 tarihli ve 6428 sayılı "Kamu-Özel İşbirliği Modeli ile Tesis Yaptırılması, Yenilenmesi ve Hizmet Alınması ile Bazı Kanun Hükmünde Kararnamelerde Değişiklik Yapılması Hakkında Kanun” kabul edilmiştir. Bu kanun kapsamında hayata geçirilmesi planlanan şehir hastaneleri projelerinde 2021 yılı sonuna kadar 18 hastanenin yapımının özel sektör tarafından tamamlanması ve Sağlık Bakanlığına teslim edilmesi öngörülmektedir. Sağlık hizmet sunumunda yeni olan bu sistem, çekirdek sağlık hizmetlerinin kamu sektörü diğer destek hizmetlerinin ise yüklenici firma tarafindan yerine getirilmesini sağlayan çift başlı örgütsel ve yönetsel yapıya sahiptir. Dolayısıyla bu çalışmada yetki ve sorumluluk dengeleri açısından yeni bir durum ihtiva eden şehir hastanelerinin yönetsel yapıları analiz edilmiştir.

Anahtar Kelimeler: Yeni Kamu İşletmeciliği, Kamu-Özel Ortaklığı, Şehir Hastaneleri.

\section{INTRODUCTION}

The theoretical and conceptual concentrations experienced in public administration in the last quarter of the 20th century opened the door to a paradigmatic transformation. Although there are many factors that cause this 
The Public-Private Partnership Model in the New Public Management Paradigm...

transformation, the social transformation created by neo-liberal policies and technological developments has played a leading role. Public administration, which grows structurally and functionally in order to meet the ever-increasing and diversifying social expectations; faced with challenges specific to the period, unlike the past problems and which cannot be solved with the existing organizational structure and understanding (Yavuz, 2018, p.119-128). In this period, which requires a different organizational and relationship network from the traditional management approach, the New Public Management (NPM) approach, which prioritizes the cooperation between public administration and business administration, has come to the fore. With the new understanding, it is observed that the relations between the individual and the state, public organizations and political authority have begun to change radically. Finally, public service and citizen perception have begun to be explained with business management components. Aftershocks triggered by social transformation have brought along new and innovative approaches in public service delivery. However, the administrations, which are also faced with the pressures originating from the budget, have tended to apply the Public Private Partnership models more within the scope of NPM (Torchia, Calabrò and Morner, 2013, p.1-26; Sezgili, 2019, p.2804-2826).

It is possible to trace the foundation of the Global Public Private Partnership (PPP) model back to the 17th and 18th centuries. The states, which are on the way to becoming a nation-state, have started to make investments and services that can be classified as infrastructure services needed by the public; such as road (land-iron), canal, bridge, tunnel, dam, drinking water-irrigation and treatment/sewage facilities, communication and tourism investments, commercial enterprises-factories, sports and cultural facilities, dormitories, all kinds of natural and solid waste heating systems , hydroelectric power plants, mining processing facilities, large-capacity parking projects, concession system, sea and airports, etc. In the 19th century, some specific infrastructure services in Europe and again in the 20th century, many cooperation practices, especially the construction of transportation networks, were realized through the public-private sector (Gökkaya, Eroymak and İzgüden, 2018, p.2235-2243).The PPP model that brings together the public and private sectors involves sharing the risk with the private sector components at the point of designing, financing, constructing, operating a public service and/or project, or revising the existing facility, strengthening its infrastructure and making it more functional (Joyner, 2007, p.205-217). Especially in the PPP model, it is also possible for the investment and service cost to be guaranteed by the treasury by the public administrations in order to encourage the private sector to share risks. Thus, it is aimed to continue 


\section{Berat AKINCI}

and conclude the services that constitute the subject of public-private partnership, regardless of any reason. Ultimately, this union, which covers many years, is based on a contractual relationship that imposes various rights and responsibilities on both parties (Sözer, 2013, p.215-253).

In our country, where the PPP model is implemented with the Build-LeaseTransfer (BLT) method in the provision of health services, it covers the construction of a health facility by the private sector in return for a rental fee or undertaking the maintenance, repair and repair works of existing health facilities. Within the scope of this model, the public administration accepts the private sector to provide some medical support services (Laboratory, imaging, sterilization) other than core health services and services such as cleaning, security, cafeteria, which are a part of the service delivery, are outside of medical services.

Thus, integrated health facility/city hospitals, which are one of the most important pillars of the health transformation project with the BLT method, started to serve (Esam, 2017, p.3).

\section{CONCEPTUAL FRAMEWORK}

\subsection{New Public Management Approach in Public Administration}

The inadequacy of the understanding of the welfare state to cope with the global crisis that started with the oil crises in the 1970s necessitated the redesign of the public administration on the basis of efficiency and productivity. Undoubtedly, the main reason behind this necessity was that diversified public services and increasing costs brought more and more burden on the budget (Eryllmaz, 2011, p.38-40). Those who see the recipe for getting out of the crisis in the implementation of neo-liberal policies have envisaged a minimal state, as well as an administrative structure that will provide economic, effective and effective public service, with the mention that the role of the state should change. Such a paradigmatic evolution; It has paved the way for the use of business techniques in public administration that will produce solutions to complaints such as inefficiency, clumsiness, excessive adherence to rules, paperwork, centralism and excessive hierarchy observed in the traditional public administration approach. Ultimately, the New Public Management (NPM), which emerged at the point of effective and efficient provision of public services, has been applied in the public sector in many new understandings from strategic management techniques used by private sector components, to specific performance criteria, 
The Public-Private Partnership Model in the New Public Management Paradigm...

from result-oriented, transparency and accountability, from customer orientation to governance (Kurun, 2017, p.85-106; Ömürgönülşen, 1998, p.517-565).

Hood (1991, p.1-20), who used the concept of New Public Management for the first time in his article titled "A Public Management for All Seasons", integrated theory and practice by pioneering not only the conceptualization of NPM, but also the need to reform the public administration structure. The rise of the minimal government trend, which is the basis for the reform of the Hood management structure, the delivery of public services by local dynamics and private sector components, the development of production and information technologies, and the addition of public policies to the global system have shown. Osborne and Gaebler (1993), on the other hand, attribute the restructuring of public organizations to ten basic principles. From this point Osborne and Gaebler;

$\checkmark$ Public administrations to act as a guiding catalyst rather than production itself,

$\checkmark$ The state is not a monopolist, free entrepreneurs produce under competition and market conditions,

$\checkmark$ Determination of goals and objectives clearly (Public agents take a more active role in determining and achieving goals),

$\checkmark$ Considering outputs and results rather than processes,

$\checkmark$ Giving importance to predictive, participatory and centrifugaldecentralized management, suggested (Osborne and Gaebler, 1993).

Prioritizing the downsizing of the state and strengthening the market, NPM is an approach that focuses on the effective and efficient use of public resources. Ultimately, on the one hand, scarce resources are channeled to the right places, while on the other hand, it is ensured that public resources are transformed into productive outputs with new techniques, new organization and target awareness.

\subsection{The Public-Private Partnership Model and Reflections}

The story of the PPP model, which started in only a few sectors, dates back to the 17 th century. However, when it comes to the end of the 20th century, it is seen that it has started to be applied in a very wide area and large-scale projects, especially with the NPM approach. It can be said that the PPP model's role as a shield against the opponents of privatization was also a factor in the acceleration gained in this period. From this point of view, states were more interested in the PPP model in order to reduce the reactions of the opponents of privatization (Sözer, 2014, p.215-253). Dominated by the trend of market strengthening and 
private delivery of some public services, the UK has become one of the largest markets for the PPP model. England, which has a very important place in the development of the PPP model in the historical process, has established the PPP model, which started with road construction projects, on a more solid foundation with the establishment of the "Private Finance Initiative (PFI). The steady increase that started in the early 1990s despite different governments has turned into a brand where PPP models are used in many different ways and at different levels of intensity. In this way, governments were able to perform vital public services with long-term contracts and financing support from the private sector. In fact, in 2009, 159 hospitals, which correspond to $90 \%$ of hospitals throughout the country, were established by PFI initiatives (Sözer, 2013, p.215-253). In Spain, in 1999, the first PPP, the "Alzira Model", was developed in order not to interrupt the delivery of health services due to the problems caused by the economic crisis. Within the scope of the contract, the construction of the "Hospital de la Ribera" hospital was ensured by sharing the risk with a private contractor. Since then, four more PPP models have been included in the application to provide health services to a population of 4.7 million, namely Torrevieja in 2006, Denia and Manises in 2009, and Vinalopo in 2010 (Tarazona, Collado and Consuelo, 2016, p.1-7). The successful implementation of the model in the UK despite some criticisms about cost has inspired many countries in the global arena. Although there were a limited number of countries that implemented the PPP model in the 2000s, many countries with different socioeconomic structures have started to use this model since then (EPEC, 2012, p.141; Boz, 2013, p.277-332).

Apart from some basic principles, there are also differences of opinion in defining the PPP model, which has such a wide geographical area of use. However, based on the accepted basic principles; It can be defined as the cooperation established on the basis of a long-term contract, in which the private sector undertakes an obligation at the risk ratio agreed by the public authority and the parties with real or private sector legal entities for the purpose of performing a public good or service (Joyner, 2007, p.207). From this point, while the public authority does not lose its control over public services, it is aimed to earn income at the rate of risk transferred to the private sector. Thus, a cooperation that benefits both parties emerges with a win-win understanding based on mutual rights and responsibilities (Uysal, 2019, p.877-898). Within the framework of this cooperation, while the private sector provides services related to the financing, construction, renewal, operation and maintenance of public infrastructure facilities, the public sector has traditionally carried out an activity that should be provided by itself, together with the private sector (Sözer, 2013, p.215-253). 
The Public-Private Partnership Model in the New Public Management Paradigm...

The European Union, on the other hand, has chosen to use an umbrella language that draws general lines rather than making a detailed description of the PPP model. In this context, PPP is defined as an upper concept that emphasizes participation between public authorities and the private sector at the point of providing public goods and services, as well as joint participation. This model, which has a different content and structure, leaves the fulfillment of public services with long-term contracts under the responsibility of neither the state nor the private sector. Today, the PPP model, which is shaped according to the participation and risk-sharing of the private sector, the method of financing, the service fee to be paid and how this payment will be made; It continues to be implemented with approaches such as build-operate-transfer (BOT), buildoperate (BO), build-lease-transfer (BLT), transfer of operating rights and revenue partnership (Boz, 2013, p.277-332).

\section{PUBLIC-PRIVATE PARTNERSHIP MODEL IN HEALTH SERVICE PROVISION: CITY HOSPITALS}

\subsection{Transformation in Health Services and City Hospitals}

Since the 1980s, the interest of private sector entrepreneurs has increased in the health sector, as in many other sectors, in the company of neo-liberal policies. Considering that the provision of health services is a public service that cannot be postponed or deferred for all citizens, it can be said that it is vital for governments to develop new models to meet the increasing health care expenditures. This situation is considered as a process felt in all developing and developing countries rather than being an issue only related to Turkey. Although the implementation examples vary from country to country, the more widespread activity of the private sector did not leave many options for the public sector, which lagged behind technological developments. From this point of view, PPP models applied globally in health service delivery; It has been widely used for purposes such as creating the infrastructure of health institutions at every level, providing health services when necessary, developing medical devices, equipment and drugs, distributing all kinds of medical devices, equipment and drugs, and ensuring the follow-up and control of diseases together with the public sector in infectious epidemics. Such a process indirectly brought about the change of health institutions both in terms of finance and organization (Uysal, 2020, p.935-960).

So much so that the construction of hospitals on a global scale with the PPP model has also attracted the attention of Turkey, which sets clear goals in 


\section{Berat AKINCI}

the provision of health services. The "Health Transformation Program (HTP)", which was launched in 2003 with the main idea of accessible, sustainable and quality health care for all, became a milestone in the realization of this interest. HTP (Recep Akdağ-2003), which is described as one of the important turning points of the health policies implemented throughout the history of the newly established republic (Dr. Refik Saydam period-1923, Dr. Behçet Uz period-1946 and Prof. Dr. Nusret Fişek-1963) In his presentation, he added participatory, solution-oriented and democratic decision-making processes on top of the work done from the past to the present. The aim of all these transformations is to provide health services in a human-oriented, effective, efficient and fair manner and to provide resources for health services. Undoubtedly, taking into account the "Health for All in the 21st Century" policy of the World Health Organization with the fact that the individual is protected together with public health, the HTP continues to be carried out with a content compatible with the experience and recommendations of international organizations. With the transformation of health services within the framework of HTP, it is aimed to reach a more dynamic administrative and organizational structure against national-global service expectations (Akdağ, 2012, p.7-9).

Within the scope of the HTP, an article was added to the 'Health Services Basic Law No. 3359 of 1987 ' in order to strengthen the health infrastructure, to benefit from the knowledge and experience of the private sector in the provision of health services, to set quality standards open to global competition, and most importantly to reduce the share of health expenditures in the budget (Annex. -7.) has been added. After this first step taken on behalf of the PPP model in health service delivery; health facilities, which were decided to be built by the High Planning Council, were allowed to be built by real or private legal entities for a certain period of time and for a certain price, provided that the preliminary projects and basic standards are determined by the Ministry of Health. The legal regulation that more clearly determines the PPP model to be made by the Ministry of Health through tenders on immovables belonging to itself or the treasury, is the Law No. 6428 of 2013 on the "Law on the Construction, Renovation and Service Procurement with the Public-Private Partnership Model and Amendments to Certain Decrees with the Force of Law".The aforementioned law abolished the validity of Article 7, supplemented by Law No. 3359. From this point, alternative approaches such as build-operate (BO), build-operate-transfer (BOT), build-lease-transfer (BLT), transfer of operating rights and revenue partnership, which are sub-models of the PPP model, gained weight in practice. However, among these, BLT has more widespread use in the private sector 
The Public-Private Partnership Model in the New Public Management Paradigm...

construction of integrated health campuses and city hospitals (Keskin, 2011, p.17; Boz, 2013, p.277-332).

BLT, which is a prominent model especially in the construction of health, education and public buildings, starts with the establishment of independent and permanent rights of construction to the private sector on the treasury-owned immovables of the needed public service. Subsequently, it continues in the form of planning, providing resources, constructing, and leasing the said goods or services to the public for a certain price and period during the operation by private-sector contractors. Core health services to be provided during the operation period (usually determined as 25 years for city hospitals), which starts at the end of a certain construction period (usually determined as 3 years for city hospitals), must be carried out by public agents, and some support and technical services must be carried out by the contractor firm (Uysal, 2019, p.877-898; Karahanoğulları, 2011, p.81).

In this period, which includes many changes and transformations in the administrative and organizational context, it is also aimed to ensure that citizens with health care needs can have all their diagnoses and treatments done in a single center without going too far. The Minister of Health of the time, Recep Akdağ, explained the purpose of opening the city hospitals, which will be built using the capital and experience of the private sector, from four different windows. These targets are shown below in the tabular form. 


\section{Berat AKINCI}

\section{Table 1}

Purposes of Opening City Hospitals from Different Perspectives

\begin{tabular}{|c|c|c|c|}
\hline $\begin{array}{l}\text { Increasing Health } \\
\text { Service Efficiency }\end{array}$ & Social Needs & $\begin{array}{c}\text { Patient Focused } \\
\text { Service } \\
\text { Approach }\end{array}$ & $\begin{array}{c}\text { In terms of } \\
\text { Health Personnel }\end{array}$ \\
\hline $\begin{array}{l}\text { To provide } \\
\text { diagnosis and } \\
\text { treatment diversity } \\
\text { in Turkey, } \\
\text { To complete the } \\
\text { developments in } \\
\text { the field of health } \\
\text { in all regions, } \\
\text { To provide quality } \\
\text { health care, } \\
\text { To provide cost- } \\
\text { effective } \\
\text { healthcare. }\end{array}$ & $\begin{array}{l}\text { To reach the number of } \\
\text { qualified and sufficient } \\
\text { beds, } \\
\text { Professional healthcare } \\
\text { team to start providing } \\
\text { effective service in all } \\
\text { regions, } \\
\text { Application of } \\
\text { technological } \\
\text { developments in } \\
\text { diagnosis and } \\
\text { treatment, } \\
\text { Development of new } \\
\text { concepts in therapeutic } \\
\text { services. }\end{array}$ & $\begin{array}{l}\text { Shortening } \\
\text { hospital stays, } \\
\text { Reduction of } \\
\text { patient transfer, } \\
\text { Reducing } \\
\text { nosocomial } \\
\text { infections, } \\
\text { Improving } \\
\text { patient safety } \\
\text { and } \\
\text { satisfaction. }\end{array}$ & $\begin{array}{l}\text { Increasing } \\
\text { employee safety } \\
\text { and satisfaction, } \\
\text { Increasing } \\
\text { workforce and } \\
\text { service quality, } \\
\text { Improving health } \\
\text { service } \\
\text { performance. }\end{array}$ \\
\hline
\end{tabular}

Source: Akdağ, 2012, p.289.

In order to ensure coordination between the city hospitals to be opened for these purposes and the contractor company, the Public Private Partnership Department (PPPD) was established within the Ministry of Health in 2007 and started its activities. At the first opportunity, it is planned to build a total of 30 health campuses with different bed numbers and physical sizes in 22 provinces (Akdağ, 2011, p.43). The hospitals that have been completed and are under construction from these projects are shown in the table below. 
The Public-Private Partnership Model in the New Public Management Paradigm...

Table 2

City Hospitals Putting into Service and Continuing Construction with the PPP Model

\begin{tabular}{lcc}
\hline \multicolumn{1}{c}{ City Hospital } & Patient Bed Capacity & Opening Period \\
\hline Yozgat City Hospital & 475 & \\
Isparta City Hospital & 755 & \\
Mersin City Hospital & 1294 & \\
Adana City Hospital & 1550 & \\
Kayseri City Hospital & 1607 & Opened between \\
Elazı̆ City Hospital & 1038 & $2017-2020$ \\
Manisa City Hospital & 558 & \\
Eskişehir City Hospital & 1081 & \\
Ankara-Bilkent City Hospital & 3711 & \\
Tekirdağ City Hospital & 486 & \\
Konya Karatay City Hospital & $838(1250$ Kapasiteli) & \\
Bursa City Hospital & 1355 & Planned to enter \\
İstanbul Başakşehir City Hospital & 2682 & service in 2021 \\
Kocaeli City Hospital & 1210 & \\
Ankara-Etlik City Hospital & 3624 & Planned to enter \\
Kütahya City Hospital & 610 & service after 2021 \\
İzmir Bayraklı City Hospital & 2060 & \\
Gaziantep City Hospital & 1875 & \\
Şanlıurfa City Hospital & 1700 & \\
\hline
\end{tabular}

Source: Ministry of Health (PPPD), 2021.

Within the framework of the BLT model, 13 of the city hospitals planned since 2012 have been put into service. In the city hospitals, 6 of which were opened/will be opened in 2021 to be carried out in different provinces and 1 of which is planned to be opened after 2021, studies are continuing rapidly. The need and demand for city hospitals reached its peak during the Covid-19 pandemic that broke out at the end of 2019, and it was seen that these hospitals fulfill an important mission in the provision of health services. While it was planned to build a limited number of city hospitals, which were subject to intense criticism due to scale, investment amount and guarantees, it is expected to increase in the following years due to the demand for qualified patient beds during the pandemic process (Gökkaya et al., 2018, p.2235-2245).

\subsection{Dualist Administrative Structure of City Hospitals}

The PPP model, which has been widely applied in different countries with different sub-models after the 1980s, has started to be used in the provision of health services, especially in the transportation and education sectors in Turkey. In the process that started with the law numbered 3359 in 2005, integrated health 


\section{Berat AKINCI}

campuses and city hospitals started to be designed as of 2012 (SBB, 2019). Criticisms have been brought against city hospitals, which started to be put into service as of 2017, on issues such as the burden on the budget due to the high cost, confidentiality of contract provisions, accountability, participation, income guarantee, location selection and accessibility, and personal rights and conditions of health workers. Today, the criticism of the PPP model mostly focuses on the fact that health institutions are privatized and the financial burden that will be undertaken for many years on the grounds of trade secrets is hidden from the public. It is possible to encounter similar criticisms in the literature regarding these issues (Torchia et al., 2013, p.1-26; Uysal, 2019, p.935-960; Kurun, 2017, p.85-106). However, in this study, the dualist (dual) management structure of city hospitals will be discussed.

There are two separate tasks sharing in the provision of health services in city hospitals built with the PPT model. Just to put it roughly; the core health service to be provided in hospitals will be provided by the public sector and its personnel, and technical support services other than these services will be provided by the private sector and its personnel. Although chief physicians are responsible for the qualified, effective and continuous delivery of health services, the contractor company uses its own procedures and methods in the performance of support services that are under the responsibility of the private sector. From this point of view, the purposeful and managerial differences in the fulfillment of health service delivery cause some controversial situations. In particular, the contractor firm does not want to be interfered with in the fields of activity that fall under its jurisdiction. However, due to the nature of health services, team spirit and coordination are required. Any error in synchronization may jeopardize patient health and safety. Therefore, this sensitive structure that entered our lives in the health administration together with the city hospitals makes it necessary to carry out intertwined responsibilities in harmony (Karahanoğulları, 2011, p.128163). In order to avoid confusion, the services to be fulfilled by the contractor firm are listed one by one in the relevant contracts. These services are shown in the table below. 
The Public-Private Partnership Model in the New Public Management Paradigm...

Table 3

P1 and P2 Services to be provided by the Firm in the PPP Model

\begin{tabular}{ll}
\hline P1 Service & P2 Service \\
\hline $\begin{array}{l}\text { Building and Land Services Cleaning } \\
\text { Exceptional Maintenance and Repair } \\
\text { Services }\end{array}$ & Security Service, Parking Services \\
$\begin{array}{l}\text { Ground and Garden Maintenance } \\
\text { Services }\end{array}$ & $\begin{array}{l}\text { Laundry and Laundry Services, Food } \\
\text { Services } \\
\text { Sterilization and Disinfection Services }\end{array}$ \\
Waste Management Services & $\begin{array}{l}\text { Hospital Information Management } \\
\text { System (HIMS) Implementation and }\end{array}$ \\
Joint Services Management Service & $\begin{array}{l}\text { Operation Service } \\
\text { Patient Orientation and } \\
\text { Accompaniment/Reception/Help }\end{array}$ \\
& $\begin{array}{l}\text { Desk/Transport Services } \\
\text { Laboratory Services, Imaging Services, } \\
\text { Physical Therapy and Rehabilitation } \\
\text { Surnishing Service }\end{array}$ \\
Sther Medical Equipment Support & Services (Extracted) \\
\hline
\end{tabular}

Source: Gökkaya et al., 2018, p.2235-2245.

A total of 19 services, which are described as P1 and P2 services within the scope of the contract, are planned to be carried out by the contractor firm. However, it is seen that Physiotherapy and Rehabilitation Services, which are within the scope of P2 in the latest contracts, have been excluded from this scope. Therefore, the services to be performed by the company within the scope of P1 and P2 have been reduced to 18. Fixed, amount-dependent (imaging, laboratory, waste management, laundry and laundry, food and sterilization and disinfection services) and non-service provisions are paid to the contractor company every month by paying progress payments over the prices specified in the contract. However, polyclinic and services for direct diagnosis and treatment are provided through the management and personnel of the Ministry of Health within the scope of core health services. At the point of fulfilling the responsibilities of the public and private sectors, the task of coordinating was left to the City Hospitals Coordination Department (CHCD), which was established within the ministry. For this purpose, training and documentation, help desk and coordination, medical services and process management, administrative, financial and legal processes and pre-operation preparation units have been established in CHCD. Thus, the contractor firm carries out support services under the supervision and control of the Ministry of Health. Every transaction and activity performed by the contractor company incompletely or incorrectly is scored and penalized. Therefore, the audit duty of the public has a very important place in the fulfillment 


\section{Berat AKINCI}

of support services according to contractual obligations (Karahanoğulları, 2011, p.128-163; Uysal, 2019, p.935-960).

Administrative sustainability is extremely important in city hospitals, which are implemented for the first time with the PPP model. Although a bilateral management structure is envisaged by the contract, it can be said that public surveillance and supervision continues. From this point of view, the perception that contractor companies manage city hospitals does not reflect reality. However, it is considered that the dual management structure may cause some managerial problems in the provision of health services. If we list these problems in items;

$\checkmark$ While hospital chief physicians are directly authorized in the provision of core health services in city hospitals, there is an indirect use of authority in support services. In this process, the approach of the business managers appointed by the contractor company directly affects the quality of health service delivery. The hybrid nature of health services also necessitates the timely, complete and uninterrupted fulfillment of support services. From this point, it is vital for both parties to act with the awareness of team spirit and responsibilities. However, it is not possible to say that this is always the case in practice. Although penal sanctions are imposed on the contractor company for incomplete and faulty procedures, patient safety and the continuity of health service delivery are at risk.

$\checkmark$ In the hospitals of the city, where different dynamics are intertwined, the managers of the contractor companies, who do not have experience in providing health services, come face to face with public employees. The lack of auxiliary health personnel, especially during the outpatient clinic, makes the relations between patient-physician and physician-health administration quite tense. Due to the prolongation of the processes, the patients have to choose between patient density and providing quality health services. This table also causes communication accidents between the managers of the contractor companies and the health workers. It is known that this form of communication without a winner creates administrative weaknesses in terms of the principle of accountability.

$\checkmark$ The holistic structure of health services should not be left dependent on a dual bureaucracy that evokes duality in administration. In fact, in city 
The Public-Private Partnership Model in the New Public Management Paradigm...

hospitals where a wide variety of services requiring expertise are provided, inspection and surveillance activities should be combined under a single administrative roof. From this point, the application of 3000-4000 pages contract contents to the public sector, the support of experts who have a good command of the accounting and purchasing processes, should monitor and audit the private sector. Because while the contractor firm employs expert personnel, it will not be possible for the personnel with classical hospital experience in the public sector to supervise and balance these people. As a result, in order for the public administration to take the initiative, from the implementation of the legislation to the resolution of the collusive issues, it must be at least as competent as the private sector.

$\checkmark$ The increase in hotel services and indoor areas in city hospitals is not in line with the increase in health personnel. While it is possible to provide a qualified response to the increasing service demand with a realistic human resources planning, on the other hand, it should be ensured that experienced personnel adapted to the new process are included in the process. Otherwise, many problems that affect the service quality during the day may be overlooked. However, although some problems can be detected by the feedback of the patients, the contractor company can hide the problems in order not to be penalized and to prevent the creditors from being affected by this situation. This situation adversely affects the delivery of health services and therefore patient care.

$\checkmark$ While public personnel work in many fields such as laboratory and imaging services, among the P1 and P2 services offered under the contract with the contractor company, inexperienced company personnel are employed instead. Especially in these two areas, high staff turnover rates affect the service quality on the one hand and cause disruptions in the work on the other hand. Experienced public personnel working in these fields are employed in less important jobs. This situation increases the work stress of the health personnel and disrupts the work peace.

$\checkmark$ It is not made in writing to convey the problems that occur especially in maintenance, repair and technical services in the hospital to the managers of the contractor company. In some hospitals, the mail method is carried out, while in some hospitals, it is carried out by sending a message on the 


\section{Berat AKINCI}

phone. Ultimately, these problems, which need to be intervened within a certain period of time, are added to the personal or systemic problems arising from communication mechanisms, making it difficult to follow up the liabilities of the companies. Ultimately, the decision-making mechanism of the public administration, which undertakes the task of supervision and control, regarding the incomplete and timely activities in question is adversely affected by this process.

$\checkmark$ For the services to be provided in the city hospitals, especially in the clinics, the contractor company is consulted before the purchasing processes for the fixtures, medical-biomedical devices and furnishing items other than consumables. The fact that the content and operating procedure of the processes such as Annex-13, Annex-17 and Annex-22, which are currently included in the contract, are not clarified, invites delay in purchasing processes. Considering that the procurement of all kinds of goods and services in other public hospitals is under the responsibility of the chief physicians, the simultaneous involvement of the purposeful differences in the processes may cause the process to go to arbitration. This situation may cause chronic managerial confrontations between the public administration and the contractor company, and it will also open the door for patient safety to be always at risk.

\section{CONCLUSION}

Integrated health campuses and city hospitals, which are the last phase of the Health Transformation Project, have started to be implemented through the sub-model of the Public Private Partnership model, Build-Lease-Transfer. In this context, financing, maintenance, repair and renewal services in the city hospitals put into service are provided by the contractor company, while the core healthcare service and customer guarantee is provided by the public sector. City hospital contracts, which require long-term cooperation between the contractor company and the public administration, consist of a certain construction period (average 3 years) and operation period (average 25 years). The private sector provides support services (HIMS, Patient Guidance, Security, etc.) on the one hand, operates commercial areas such as parking lots and cafeterias, on the other hand, in accordance with its contractual obligations. Thus, the Ministry of Health, as a public administration, both solves the resource problem with the Build-Lease- 
The Public-Private Partnership Model in the New Public Management Paradigm...

Transfer model and enters the long-term business process with the private sector within the framework of the New Public Management approach.

The Public-Private Partnership model is implemented in hybrid city hospitals over a relationship network (public administration-contractorfinancier/creditor) and an administrative structure that public administrations are not accustomed to. It is vital that these gigantic projects include conditions that will ensure optimal healthcare delivery. In addition, an effective monitoringevaluation and performance audit should be carried out throughout the operation process in order to increase the quality of service and to establish a cost-effective health service balance (SBB, 2019). While the importance of all these for the success of the project is obvious, it is equally important to ensure administrative sustainability for service quality. In the "Specialization Commission Report" published by the Ministry of Development, this situation was clearly stated and it was emphasized that the sustainability of the projects should be continued without causing administrative problems rather than the size of the hospitals. From this point, the risk of mismanagement approaches both in terms of finance and public health has also been revealed (Ministry of Development, 2018).

It is extremely important to minimize administrative problems in terms of the sustainability of public-private sector cooperation in city hospitals. In this context, it is necessary to strengthen the human resources of city hospitals, which will be the face of the health service delivery of our country, with a new management model unique to them. Ultimately, it is essential that the positive graphic captured in terms of the use of physical space in hospitals is also captured in organizational arrangements and in creating corporate culture. In this context, trainings should be given urgently to both public personnel and private sector employees in accordance with the new management approach and contributing to the formation of corporate culture. In particular, priority should be given to the fact that the business managers appointed by the contractor company have assimilated the Public Private Partnership model, which requires working together for many years, and have experience suitable for joint and teamwork. The length of the contractual provisions for the construction and operation process puts a lot of strain on the public administrators responsible for the supervision and control of hospitals. For this reason, the applicability of the said contract and legislation provisions should be increased by simplifying them by experts. Because ambiguous or open to interpretation texts make it difficult to solve the problems experienced in the field and cause the process to be carried to the judiciary. Again, instead of the City Hospitals Coordination Department established before the ministry, it should be ensured that the services are carried out and observed at the level of the executive general directorate or directly under 


\section{Berat AKINCI}

the responsibility of a deputy minister. Local political interventions should be prevented in the appointment of managers who are in the position of institutional memory, by reducing the turnover rate of both managers and health personnel in city hospitals. From this point of view, managers who are qualified and experienced in the management of hybrid health institutions should continue their duties. Most importantly, instead of a dualist management structure, the practice of "Professional Hospital Management", which dominates business, law and health practices, should be started as soon as possible. Professional hospital manager should be responsible for the general management of city hospitals with his knowledge and experience. Under this management, a chief physician can be appointed for core service delivery and a business manager for other support and technical services. It should be ensured that both managers work in coordination with each other and depending on the Professional Hospital Manager. Thus, the hospital head physician will focus on performing only core health services and the operating manager will focus on performing other support services without having to deal with many administrative regulations. As a result, thanks to Professional Hospital Management, the expectation of accessible, qualified health services expected from city hospitals and sustainable private sector cooperation will be realized without any managerial turmoil.

\section{REFERENCES}

Akdağ, R. (2011). Sağlık Bakanlı̆̆ı Yataklı Sağlık Tesisleri Planlama Rehberi (Özet Kitap). Tedavi Hizmetleri Genel Müdürlüğü.

Akdağ, R. (2012). Türkiye’de Să̆lıkta Dönüşüm Programı Değerlendirme Raporu (2003-2011). https://sbu.saglik.gov.tr/Ekutuphane/kitaplar/SDP turk.pdf, Access date: 08.12.2020

Boz, S.S. (2013). Kamu özel işbirliği (PPP) Modeli. Inönü Üniversitesi Hukuk Fakültesi Dergisi, 4(2), 277-332.

ESAM (2017). Să̆lık Politikaları ve Şehir Hastaneleri Çalıştayı Sonuç Bildirgesi. http://www.esam.org.tr/pdfler/Raporlar/Sa\%C4\%9Fl\%C4\% B1k\%20Politikalar\%C4\%B1\%20ve\%20\%C5\%9Eehir\%20Hastaneleri\% 20Sonu\%C3\%A7\%20Bildirgesi.pdf, Access date: 08.12.2020

Ery1lmaz, B. (2011). Kamu Yönetimi: Düşünceler, Yapılar, Fonksiyonlar, Politikalar. Okutman Yayıncılık. 
The Public-Private Partnership Model in the New Public Management Paradigm...

European PPP Expertise Centre (EPEC). (2012). UK (England) - PPP Units and Related Institutional Framework, Jule 2012, ss.1-41, https://www.eib.org/attachments/epec/epec_uk_england_ppp_unit_and_ related_institutional_framework_en.pdf, Access date: 08.12.2020

Gökkaya D., Eroymak, S. \& İzgüden, D. (2018). Kamu özel ortakliği bağlaminda şehir hastanelerinin değerlendirilmesi. Social Sciences Studies Journal (SSSJournal), 4(19), 2235-2243.

Hood, C. (1991). A public management for all seasons. Public Administration, 69, 3-19.

Joyner, K. (2007). Dynamics evolution in public-private partnerships, the role of key actors in managing multiple stakeholders. Managerial Law, 49(5/6), 205-217.

Kalkınma Bakanlığı (2018). On Birinci Kalkınma Planı (2019-2023). Sağlık hizmet kalitesi ve mali sürdürülebilirlik özel ihtisas komisyonu raporu.

Karahanoğulları, O. (2011). Eksik Imtiyaz (Kamu-Özel Ortakliğı). Sağlık Alanında Kamu-Özel Ortaklığı Sempozyumu 6-7 Mayıs 2011, 128- 163.

Keskin, S., (2011). Türkiye'de Sağlık Hizmetlerinin Sunumunda Kamu Özel Ortakıı̆̆1 Modeli (Aydın Örneği). Yayımlanmamış yüksek lisans tezi, Adnan Menderes Üniversitesi Sosyal Bilimler Enstitüsü.

Kurun, İ. (2017). Yeni kamu işletmeciliği yaklaşiminin kamu hizmetlerine etkisi: Belediyeler örneği. Bartın Üniversitesi İ.I.B.F. Dergisi, 8(16), 85-106.

Mariateresa T., Andrea C. \& Michèle, M. (2013). Public-Private Partnerships in the Health Care Sector: A systematic review of the literature. Public Management Review, 1-26, http://dx.doi.org.10.1080/14719037.2013. 792380

Osborne, D. \& Gaebler, T. (1993). Reinventing Government: How the Entrepreneurial Spirit is Transforming the Public Sector. Reading.

Ömürgönülşen, U. (1998). The emergence of a new approach to the public sector: The new public management. Ankara Üniversitesi Siyasal Bilgiler Fakültesi Dergisi, LII(1-4), 517-565.

Sezgili, K. (2019). Kurumsal politik davranış: İşletme, devlet ve piyasa ilişkileri ekseninde eleştirel bir inceleme. OPUS-Uluslararası Toplum Araştırmaları Merkezi, 13(19), 2804-2826.

Strateji Bütçe Başkanlığı (SBB) (2019). On Birinci Kalkınma Planı (2019-2023). 


\section{Berat AKINCI}

SB KÖODB (2021). Şehir Hastanelerimiz, https://khgmsehirhastaneleridb. saglik.gov.tr/TR-43796/sehir-hastanelerimiz.html, Access date: 20.10. 2021

Sözer, A.N. (2014). Sağlikta yeniden yapilanmanin (özelleştirmenin) devami olarak şehir hastaneleri. Dokuz Eylül Üniversitesi Hukuk Fakültesi Dergisi, 15(Özel Sayı), 2013, 215-253.

Tarazona, M.C., Collado, A.C. \& Consuelo, D.V. (2016). A cost and performance comparison of Public Private Partnership and public hospitals in Spain, Health Economics Review, 6:17, 1-7.

Torchia, M., Calabrò, A. \& Morner, M. (2013). Public-Private Partnerships in the Health Care Sector: A systematic review of the literature. Public Management Review, 1-26. http://dx.doi.org.10.1080/14719037.2013. 792380

Türkiye Cumhuriyeti Cumhurbaşkanlığı, Strateji ve Bütçe Başkanlığı (SSB) (2019). On Birinci Kalkınma Planı (2019-2023).

Uysal, Y. (2019). Kamu-özel işbirliği (Yap-Kirala-Devret) modeli ve şehir hastanelerinin sağlik hizmetlerindeki değişim ve dönüşüm üzerine etkileri. Eskişehir Osmangazi Üniversitesi İ̈BF Dergisi, 14(3), 877-898.

Uysal, Y. (2020). İngiltere kamu-özel işbirliği modelinin türkiye'deki şehir hastaneleri uygulamalari üzerine etkileri: Politika transferi bağlaminda bir analiz. Dokuz Eylül Üniversitesi Sosyal Bilimler Enstitüsü Dergisi, 22(3), 935-960.

Yavuz, H. B. (2018). The economic function of the State. Journal of Tourism and Regional Development, (9), 19-128.

\section{EXTENDED ABSTRACT}

The PPP model, which has been widely applied in different countries with different sub-models after the 1980s, has started to be used in the provision of health services, especially in the transportation and education sectors in Turkey. In the process that started with the law numbered 3359 in 2005, integrated health campuses and city hospitals started to be designed as of 2012 (SBB, 2019). Criticisms have been brought against city hospitals, which started to be put into service as of 2017, on issues such as the burden on the budget due to the high cost, confidentiality of contract provisions, accountability, participation, income guarantee, location selection and accessibility, and personal rights and conditions 
of health workers. Today, the criticism of the PPP model mostly focuses on the fact that health institutions are privatized and the financial burden that will be undertaken for many years on the grounds of trade secrets is hidden from the public. It is possible to encounter similar criticisms in the literature regarding these issues (Torchia et al., 2013, p.1-26; Uysal, 2019, p.935-960; Kurun, 2017, p.85-106). However, in this study, the dualist (dual) management structure of city hospitals will be discussed.

There are two separate tasks sharing in the provision of health services in city hospitals built with the PPT model. Just to put it roughly; The core health service to be provided in hospitals will be provided by the public sector and its personnel, and technical support services other than these services will be provided by the private sector and its personnel. Although chief physicians are responsible for the qualified, effective and continuous delivery of health services, the contractor company uses its own procedures and methods in the performance of support services that are under the responsibility of the private sector. From this point of view, the purposeful and managerial differences in the fulfillment of health service delivery cause some controversial situations. In particular, the contractor firm does not want to be interfered with in the fields of activity that fall under its jurisdiction. However, due to the nature of health services, team spirit and coordination are required. Any error in synchronization may jeopardize patient health and safety. Therefore, this sensitive structure that entered our lives in the health administration together with the city hospitals makes it necessary to carry out intertwined responsibilities in harmony (Karahanoğulları, 2011, p.128-163).

Administrative sustainability is extremely important in city hospitals, which are implemented for the first time with the PPP model. Although a bilateral management structure is envisaged by the contract, it can be said that public surveillance and supervision continues. From this point of view, the perception that contractor companies manage city hospitals does not reflect reality. However, it is considered that the dual management structure may cause some managerial problems in the provision of health services. It is extremely important to minimize administrative problems in terms of the sustainability of publicprivate sector cooperation in city hospitals. In particular, priority should be given to the fact that the business managers appointed by the contractor company have assimilated the Public Private Partnership model, which requires working together for many years, and have experience suitable for joint and teamwork. The length of the contractual provisions for the construction and operation process puts a lot of strain on the public administrators responsible for the supervision and control of hospitals. For this reason, the applicability of the said contract and legislation provisions should be increased by simplifying them by 


\section{Berat AKINCI}

experts. Because ambiguous or open to interpretation texts make it difficult to solve the problems experienced in the field and cause the process to be carried to the judiciary. Again, instead of the City Hospitals Coordination Department established before the ministry, it should be ensured that the services are carried out and observed at the level of the executive general directorate or directly under the responsibility of a deputy minister. Local political interventions should be prevented in the appointment of managers who are in the position of institutional memory, by reducing the turnover rate of both managers and health personnel in city hospitals. From this point of view, managers who are qualified and experienced in the management of hybrid health institutions should continue their duties. Most importantly, instead of a dualist management structure, the practice of "Professional Hospital Management", which dominates business, law and health practices, should be started as soon as possible. Professional hospital manager should be responsible for the general management of city hospitals with his knowledge and experience. Under this management, a chief physician can be appointed for core service delivery and a business manager for other support and technical services. It should be ensured that both managers work in coordination with each other and depending on the Professional Hospital Manager. Thus, the hospital head physician will focus on performing only core health services and the operating manager will focus on performing other support services without having to deal with many administrative regulations. As a result, thanks to Professional Hospital Management, the expectation of accessible, qualified health services expected from city hospitals and sustainable private sector cooperation will be realized without any managerial turmoil. 